https://doi.org/10.15407/ufm.19.01.049

PACS numbers: 07.75.+h, 14.20.Dh, 34.35.+a, 41.75.Ak, 61.80.Li, 68.49.Sf

V.T. CHEREPIN, M.O. VASYLYEV, I.M. MAKEEVA, and V.M. KOLESNIK

G.V. Kurdyumov Institute for Metal Physics, NAS of Ukraine, 36 Academician Vernadsky Blvd., UA-03142 Kyiv, Ukraine

S.M. VOLOSHKO

National Technical University of Ukraine 'Igor Sikorsky Kyiv Polytechnic Institute', 37 Peremohy Ave., UA-03056 Kyiv, Ukraine

\title{
SECONDARY ION EMISSION DURING THE PROTON BOMBARDMENT OF Metal suRfaCes
}

Secondary ion mass spectrometry (SIMS) is successfully used for fundamental and applied studies of the solid surfaces. Thus, it is important to know regularities in the secondary ion emission (SIE) induced by the primary beams of the inert or chemically active elements. The SIE intensity is found to be dependent not only on the surface sputtering processes (the intensity increases with the atomic number of the bombarding ion), but on the ionization probability of the sputtered atoms (the probability is strongly dependent on the physical and chemical states of target surface and experimental conditions) too. Analytical capabilities of SIMS might be improved by the use of light ions producing low sputtering and causing minimum surface erosion. The goal of the present review paper is a systematic study of various SIE aspects for metals, alloys, and chemical compounds in the case when the surface is bombarded with lightest ions-protons. To reveal the possibilities of proton applications in SIMS, the target surface was also bombarded with argon ions. The SIE regularities for metal targets were studied on the ion microprobe analyser equipped with a spherical $180^{\circ}$-sector energy analyser and a system, which pumps gas into the chamber. This made it possible to investigate not only the SIE factors, but also the secondary ion energy distribution and the change of the emission character at the target interaction with active gases. The SIE coefficients are measured for metals of I-III large periods. The use of primary protons and argon ions leads to a similar dependence of the SIE differential coefficients on the target atomic number. The SIE coefficients for primary protons and argon ions for the same elements are similar. Sputtering coefficients for the $\mathrm{Ar}^{+}$ions are known to exceed those for protons. The fact that the metal-ion emission intensity for bombardment with lighter ions commensurate with a signal of secondary ions sputtered from the surface by heavy species is of a high practical importance for use of protons with ana- 
lytical purposes. This fact may be explained as a result of extraordinary high ionization probability due to $\mathrm{H}^{+}$ions. However, along with the general regularities based on the nature of materials at hand, there are essential differences in mechanisms of the atom ionization for the sputtering by protons and inert gas ions. Therefore, we have investigated the energy distributions of metal secondary ions ejected from surface bombarded with $\mathrm{H}^{+}$and $\mathrm{Ar}^{+}$ions. It is shown that, in the case of proton bombardment of multicomponent targets, a partial suppression of the structural, phase, and other matrix effects is observed. These effects as well as the increasing ionization probability of metal atoms sputtered by protons are quantitatively described concerning the important role of the local surface bonds in the ionization mechanism.

Keywords: diffusion, martensite, austenite, radioisotope, dislocation, stacking fault defect.

\section{Introduction}

Progress in the field of fundamental and applied research of the solid surfaces is based on the continuous improvement of existing and the development of new methods for analysing the composition, structure, and properties of the surface using probing with electron, photon, and ion beams. Among the methods for studying the solid surfaces based on the ion beam probing, a special place belongs to the mass spectrometry of secondary ions. The working process in the SIMS is the SIE, which consists in the emission of ions of atoms or molecules under the influence of bombardment with primary accelerated ions. As the primary ions bombarding surface, ions of inert gases $\left(\mathrm{Ar}^{+}, \mathrm{Xe}^{+}\right)$, oxygen $\left(\mathrm{O}_{2}^{+}\right)$, as well as some metals $\left(\mathrm{Ga}^{+}, \mathrm{In}^{+}, \mathrm{Bi}^{+}, \mathrm{Cs}^{+}\right.$, etc. $)$are commonly used. As a result of numerous studies of SIE processes, a clear relationship between the nature and parameters of primary ions, composition and structure of the target, the quantitative and qualitative characteristics of ions is established. The restrictions for the SIMS applications, particularly, in case of simultaneous high layer resolution and high concentration sensitivity or locality, are also established. Processes of emission during bombardment of the surface with ions of inert gases or electronegative active gases are studied the most thoroughly [1-19].

Authors of this review paper were the first who used the most light ions (i.e., protons), which possess the lowest sputtering ratio and thus causing minimal erosion of the studied surface, in the SIMS method. The authors [20] revealed abnormally high probability of ionization of sputtered metal particles during bombardment of metallic surface with protons as compared with bombardment with ions of inert gases. This result found later its confirmation in Ref. [21]. The use of protons as bombarding ions makes it possible to expand significantly the possibilities of practical application of the SIMS method. Since ionization probability is anomalously high and the sputtering ration is extremely small $\left(10^{-2}\right.$ at./ion), at identical current density and energy of primary ions, 
bombardment with protons improves the layer resolution by two-three orders without decreasing the concentration sensitivity and locality in comparison with bombardment with commonly used argon and oxygen ions. The proton mass spectrometry can be used the most effectively for layer-by-layer analysis of very thin layers (from the fractions of a monolayer to $10 \mathrm{~nm}$ ) and interphase boundaries, as well as in construction of ion microprobe analyser with heightened sensitivity and resolution [22, 23]. Application of accelerated protons as a bombarding gas is also promising for analysis of biological objects [24-27].

It should be noted that an increase in the secondary ion emission due to the adsorption or introduction of oxygen, caesium, and other electronegative and electropositive elements is used for a relatively long time in the practice of the diagnostics of materials by the SIMS method [10-11]. Several mechanisms [28-31] explaining effect of SIE enhancement are suggested. According to electron tunnelling model [28], one can expect an exponential enhancement of ionization probability for the sputtering atoms as the work function of surface electrons increases during adsorption. Models [29-31] validate that an ionization probability does not depend on the electron work function and enhancement in SIE is caused by the formation of local chemical bonds of metal and adsorbate atoms as well as their coordination in the surface [31]. Formation of surface compounds, especially of oxides, is accompanied with rapid enhancement of secondary ion emission up to several orders of magnitude [1-3]. Such a phenomenon known as a 'chemical' or 'reaction emission' can be observed in case of proton bombardment as well. The formation due to the interaction of protons with a metallic surface of unstable hydrogen-containing hydrides and hydroxides can significantly increase the probability of atomic ionization by a mechanism similar to the mechanism of 'reaction emission'.

In order to ascertain the mechanism of interaction of accelerated protons with metallic surfaces, this review paper presents results of studies of the regularities and features of secondary ion emission during the proton bombardment of transition metals, as well as binary alloys and compounds with different chemical and phase compositions, structures, and types of interatomic bonds. We also present an interpretation of the enhancement of the secondary ion emission within the framework of known SIE mechanisms.

\section{Materials and Study Techniques}

As the main experimental parameters that enable to establish the relationship between the physicochemical properties of the studied materials and SIE, the following characteristics are used: 
(i) SIE coefficient (ratio) $K_{i}^{+}=N_{i}^{+} / N_{0}$, where $N_{i}^{+}$is quantity of secondary ions with a certain ration of the charge to the mass of $i$-th element, $N_{0}$ is a number of primary ions;

(ii) the secondary ion yield (emission) for multicomponent target $Y_{i}^{+}=K_{i}^{+} / C_{i}$, where $C_{i}$ is a concentration of $i$-th component;

(iii) sputtering coefficient (ratio) $S=N / N_{0}$, where $N$ is a total number of sputtered particles, i.e., a sum of neutral $\left(N^{0}\right)$ and ionized particles $\left(N_{i}^{+}\right)$;

(iv) ionization probability $R_{i}^{+}=K_{i}^{+} / S$ that characterizes fraction of secondary ions in a total flow of the sputtered particles;

(v) ionization degree $\alpha_{i}^{+}=N_{i}^{+} / N^{0}$; if $R_{i} \ll 1$, then $\alpha_{i}^{+}=R_{i}^{+}$.

Since determination of $S$ is a difficult experimental problem, the calculated values of this parameter are used. The calculations were carried out within the framework of the Sigmund theory [32] by means of equation [33]:

$$
S=\Lambda \frac{Z_{1} Z_{2} e^{2}}{0.88 a_{0} \sqrt{Z_{1}^{2 / 3}+Z_{2}^{2 / 3}}} \frac{M_{1}}{M_{1}+M_{2}} f(\varepsilon)
$$

here, $\Lambda$ is a coefficient characterizing the target material; $M_{1}, M_{2}, Z_{1}$, and $Z_{2}$ masses and atomic numbers of bombarding ion and atom, respectively; $e$ is an elementary electron charge; $a_{0}$ is the first Bohr radius; $f(\varepsilon)$ is a function tabulated for protons [33] and argon ions [32]. Equation (1) enables the closest evaluation of $S$ value during proton bombardment of the surface since unknown coefficients $\Lambda$ can be calculated via a direct comparison of experimental [34] and calculated values of sputtering ratios.

The objects of the study were transition metals (grades $\mathrm{O}$ and ЧДА), alloys with different phase equilibrium diagrams, binary compounds with different types of interatomic bond, and model objects where hydrogen is bound in stable compounds as an original component: $\alpha$-solid solution of hydrogen in titanium $(1.12$ at. $\% \mathrm{H})$ and $\mathrm{TiH}_{1.47}$, $\mathrm{TiH}_{1.55}, \mathrm{TiH}_{2}$ hydrides.

Investigation of the SIE of metallic surfaces at the proton bombardment is performed using the ion microprobe analyser equipped with a spherical $180^{\circ}$-sector energy analyser and system of gas inleakage into the working chamber. Such a methodology enabled to study not only the SIE coefficients but also energy distribution of secondary ions as well as changing of the character of emission when the target surface interacts with active gases [5]. After the preliminary treatment, the final purification of the samples was realized via the surface sputtering of $\mathrm{Ar}^{+}$ions directly in the working chamber of the device and controlled via the stabilization of the secondary ion current. The bombardment of the sample surfaces by the $\mathrm{Ar}^{+}$ions was also used for comparison of the 
Fig. 1. Displacement of the energy spectra of secondary argon ions under the bombardment of Mo (100) by argon ions and simultaneous adsorption of hydrogen when hydrogen pressure is $3 \cdot 10^{-4}$ (1) $9 \cdot 10^{-5}(2)$, and $4 \cdot 10^{-5}(3) \mathrm{Pa}[35]$

emission character during the sputtering of the surface by the protons and inert gas ions. In this case, the

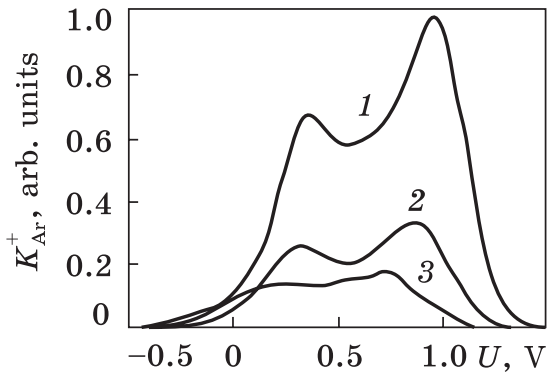
energy and current density of argon protons and ions were maintained to be constants equal to $6 \mathrm{keV}$ and $10^{-4} \mathrm{~A} \cdot \mathrm{cm}^{-2}$, respectively, the vacuum in the working chamber was kept to be as $2 \cdot 10^{-5} \mathrm{~Pa}$.

To study mechanism of influence of hydrogen on the secondary ion yield, there is a developed methodology [35] of combined measurements of the SIE and work function of electrons from the surface region directly subjected to the ion bombardment. Experimental measurements are performed using ultra-vacuum spectrometric complex with energy and angle resolutions [36]. It is important to stress that the sample and input optics of the analyser channel are grounded. Thus, the charge particles (emitted by the surface sample) move in a free-field space, and small shifts of their energy spectrum over the time-base voltage scale of the energy analyser (e.g., because of adsorption-induced change in the contact potential difference between the surface sample and analyser) are measured with a great precision that equals to $0.05 \mathrm{eV}$ [35]. Similar shifts of the photoelectric peaks are commonly used to observe variations of the electron work function [37]. However, in contrast to photoelectric energy spectrum peaks, the typical SIE energy distributions have flat branches and maximum [3, 7], the shift of which cannot be measured with a due accuracy. In consideration of the latter, for the combined study of the SIE and electron work function, it is conveniently to use specific energy distributions of the positively charged secondary ions of argon implanted out of ion beam and simultaneously yielded from the surface during the bombardment with argon ions.

The SIE argon spectra are quite narrow and have two peaks with clearly observed maximums [38]. Figure 1 illustrates the shift of such a spectrum on the energy scale of the secondary ions during adsorption of hydrogen on the Mo (100) monocrystal surface bombarded with argon ions. The residual pressure in the chamber was $10^{-8} \mathrm{~Pa}$. The argon pressure during the ion bombardment was kept on the level of $8 \cdot 10^{-7} \mathrm{~Pa}$. Spectrally clear hydrogen was obtained via the thermal decomposition of titanium hydrides. We can see in Fig. 1 that, as the hydrogen puffing, the maxima of the argon spectrum shift toward an increase in the sweep voltage of the analyser. Thus, energy of the secondary ions increases. In other words, under the influence of hydrogen, the surface of 
the sample acquires an additional positive charge, which accelerates positively charged secondary argon ions that corresponds to a decrease in the work function of the surface electrons [39]. The magnitude of the change in the work function is equal to the shift of the spectrum maxima. The absolute values of the work function were used, which were determined as the work function of electrons from the atomically pure Mo (100) surface (equal to $4.4 \mathrm{eV}$ ) minus the measured value of the shift [35].

\section{Secondary Ion Emission for Transition Metals}

The SIE coefficients (ratios) for surface bombardment with protons and argon ions under identical experimental conditions were measured for transition metals of long periods [40-41]. When protons and $\mathrm{Ar}^{+}$ions are as primary ions, the dependences of differential SIE coefficients on the atomic number of the metal $Z_{2}$ is similar (Fig. 2,a). As the $Z_{2}$ increases within the period of the periodic table, the general tendency to decreasing of $K_{i}^{+}$remains, however, the range of changes for $K_{\mathrm{Ar}}^{+}$exceeds the range of changes for $K_{\mathrm{H}}^{+}$by one to one and a half orders. All values of the SIE coefficients are represented in arbitrary units under condition that, for proton bombardment, $R_{\mathrm{Mo}}^{+}=1$.

Values $K_{\mathrm{H}}^{+}$and $K_{\mathrm{Ar}}^{+}$measured for the same elements are similar between each other. Moreover, for a series of metals, e.g., for $\mathrm{Fe}, \mathrm{Cu}, \mathrm{Zn}$, $\mathrm{Ag}$, and $\mathrm{Au}$, the SIE excited by protons is more intensive than during the sputtering of argon ions (Fig. 2,a). This fact is of interest because the sputtering coefficients of metals by argon ions $S_{\mathrm{Ar}}$ are one or two orders of magnitude higher than the values of $S_{\mathrm{H}}$ (Fig. $2, b$ ).

As one can see in Fig. 2, the explanation of this effect consists in the extremely high ionization probability of sputtered atoms under the impacts of protons. For the metals are studied, the probability of atomic ionization during the irradiation of the surface with $R_{\mathrm{H}}^{+}$protons is $2-4$ orders of magnitude higher than $R_{\mathrm{Ar}}^{+}$[40-41].

Considering the importance of the state of the surface-vacuum interface for the mechanism of secondary ion formation, the mass-spectral composition of the SIE for metals within the first large period of the periodic table under the proton sputtering was studied [40]. In the mass spectra of pure elements under the proton irradiation, mono- and polyatomic ions of the metal, its oxides and hydrogen-containing compounds are present. The study of the mass-spectral composition of the secondary positive ions, sputtered from the metal surface with an accelerated protons, showed that such a light particle as the proton induces the emission of cluster ions of the target material $M_{n}^{+}$with $n=$ $=2-9$ (depending on the target material) and complex hydrogen-containing molecular $M_{n} \mathrm{H}_{m}^{+}$-type ions, where $m=1,2,3$. These results are in a complete agreement with the results of Ref. [21], where the forma- 


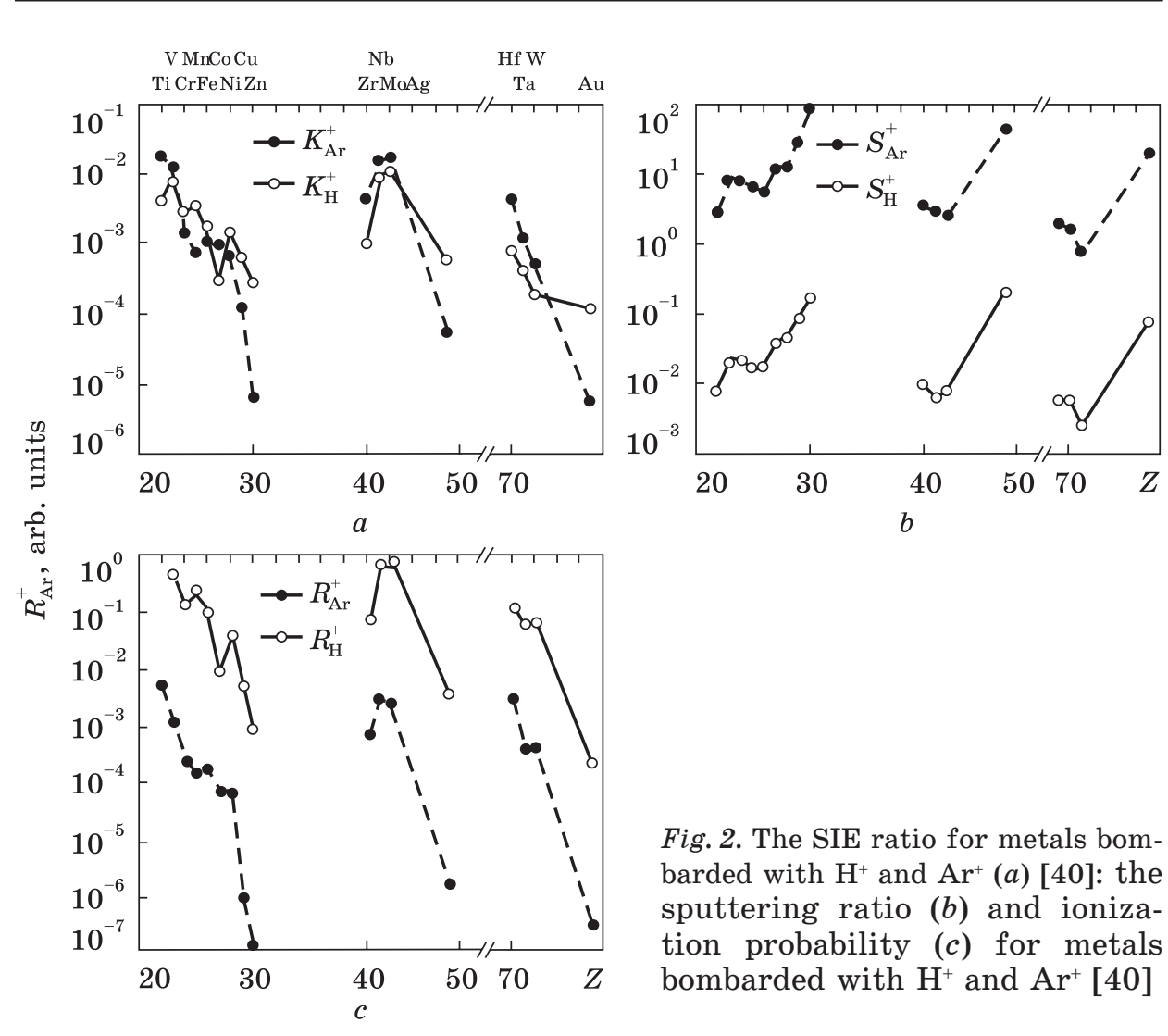

tion of polyatomic ions during bombardment of metals by hydrogen ions was studied.

Figure 3 represents the intensity of yield of polyatomic $M_{n}^{+}$and $M_{n} \mathrm{H}_{m}^{+}$ions depending on the quantity $n$ of metal atoms in $M_{n}^{+}$ion for the cases of the proton bombardment of $\mathrm{Al}, \mathrm{Ni}$, and $\mathrm{Cu}$ targets, respectively [21]. According to the existing models of statistical recombination [42] and direct liberation [43-44], the process of the cluster formation has to occur with a sufficiently high probability only at high sputtering coefficients, when $S>1$. In case of the proton bombardment of metals, we have $S \ll 1$. All this again confirms that the probability of ionization of the sputtered particles during bombardment by protons, acquires anomalously high values.

One of the most important established features is the relationship between the coefficients of proton sputtering of the investigated materials and the probability of ionization of sputtered atoms. This effect, which was observed for the first time during the sputtering of solids by argon ions [2,3], is manifested in the fact that the probability of the secondary ions formation is the highest for hardly-sputtered materials. Such a feature is explained by the important role of the characteristics 

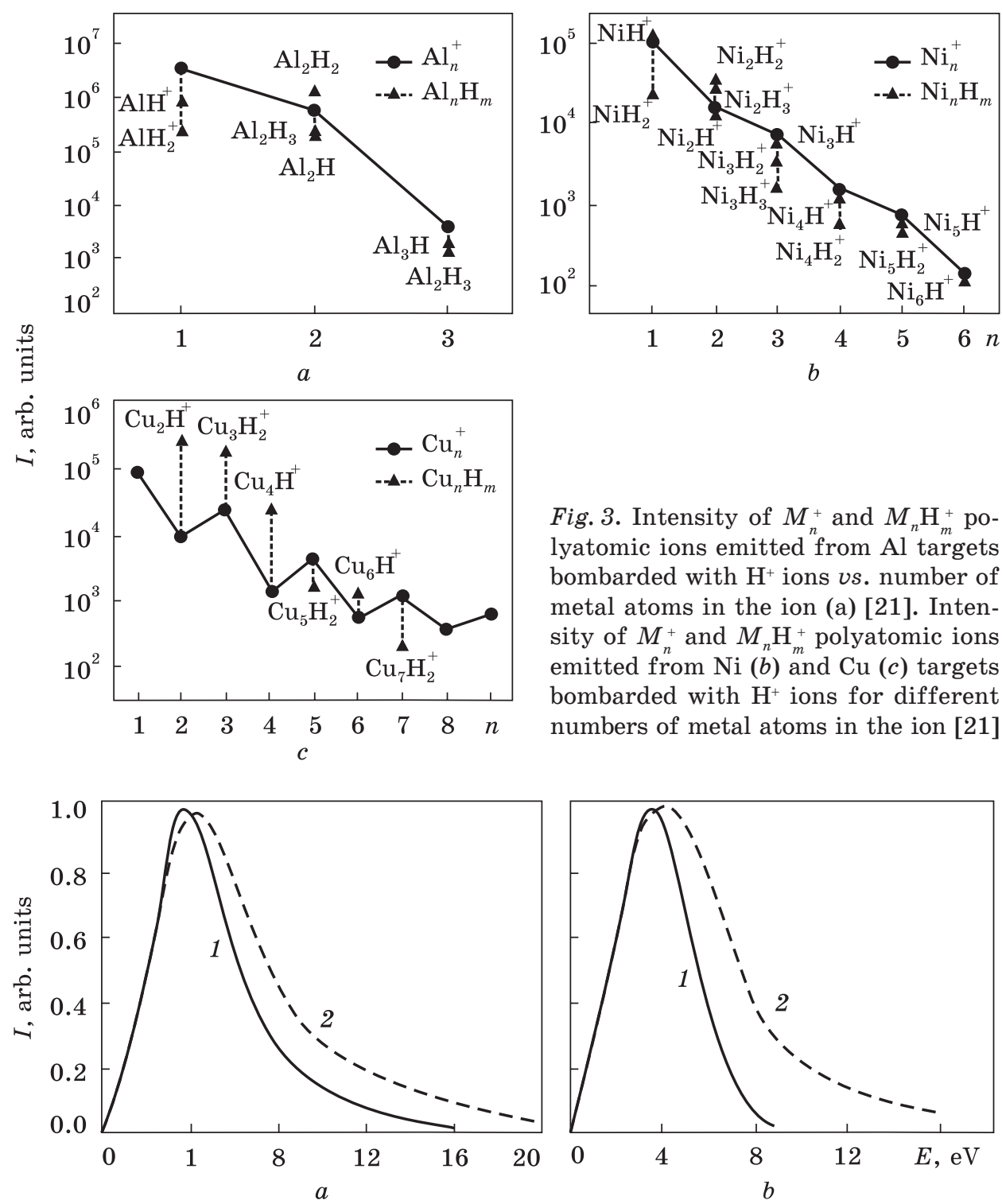

Fig. 4. Energy distributions of $\mathrm{Ti}^{+}(a)$ and $\mathrm{Zr}^{+}(b)$ secondary ions bombarded with $\mathrm{H}^{+}$ (1) and $\mathrm{Ar}^{+}$(2) [40]

of the chemical bond in the surface layer of the target material and correlates with the well-known conceptions about the mechanisms of sputtering and ionization of metal atoms [45]. According to quantum-mechanical model [45], the sputtering coefficient is inversely proportional to the bond energy of atom on the target surface $(S \sim 1 / E)$, and ionization degree is proportional to the squared bond energy in concordance 
with equation as follows:

$$
\alpha^{+}=\left(\frac{E}{I-\varphi}\right)^{2}\left(\frac{\hbar v}{a(I-\varphi)^{3}}\right)^{\kappa},
$$

where $E$ is a bond energy of the surface atom, $I$ is the first ionization potential, $\varphi$ is a work function for electron, $v$ is an average atomic sputtering rate, $\hbar$ is the Planck constant, $a$ is a thickness of the bombardment-excited surface layer, $\kappa$ is a fitting parameter.

It follows from Eq. (2) that increase in $\alpha^{+}$may be a consequence of the growth of the mean rate $v$ of the sputtered particles. An information on the average rate (average energy) of emitted particles can be obtained from the energy distributions of secondary ions. For this purpose, the energy distributions of the secondary atomic ions of transition metals were measured during proton and argon bombardment [40]. Typical energy distributions of the secondary ions are represented in Fig. 4, while Table 1 contains data on the most important characteristics of these distributions. We can see from Table 1 that energy of the maximum $E_{m}$ and half-width of the distribution $\Delta E$, characterizing average energy of the emitted ions, are lower in case of the proton sputtering as compared to the bombardment by the $\mathrm{Ar}^{+}$inert gas ions; it indicates about lower average rate of the emitted metallic ions during the proton sputtering. The similar results were obtained in Ref. [21] when authors measured energy distributions of the secondary cluster $\mathrm{Cu}_{n}^{+}$and $\mathrm{Ni}_{n}^{+}$ ions during bombardment of $\mathrm{H}^{+}$and $\mathrm{Xe}^{+}$ions. This effect can be explained, in particular, by the presence of adsorbed gas on the target surface, since emission from the adsorbate layer is often accompanied by a narrowing of the energy distribution of the secondary ions [3].

The experimentally observed increase of $\alpha_{H}^{+}$in comparison with $\alpha^{+}$ when the surface is bombarded with ions of inert gases $\mathrm{Ar}^{+}$and $\mathrm{Xe}^{+}$indicates about strong influence of additional factor, which compensates factor of ionic velocity and eventually results to rapid enhancement of the ionization probability $R^{+}$. Such a factor can be a change in the physical and chemical state of the surface as a result of its interaction with

Table 1. Maximum energy and half-width of the secondary metal ion energy distributions sputtered by protons and argon ions [40]

\begin{tabular}{|c|c|c|c|c|c|c|}
\hline$Z_{2}$ & $\mathrm{Al}$ & $\mathrm{Ti}$ & $\mathrm{Ni}$ & $\mathrm{Cu}$ & $\mathrm{Zr}$ & $\mathrm{Ag}$ \\
\hline \multirow{2}{*}{$Z_{1}$} & $\mathrm{H}^{+}$ & $\mathrm{H}^{+}$ & $\mathrm{H}^{+}$ & $\mathrm{H}^{+}$ & $\mathrm{H}^{+}$ & $\mathrm{H}^{+}$ \\
& $\mathrm{Ar}^{+}$ & $\mathrm{Ar}^{+}$ & $\mathrm{Ar}^{+}$ & $\mathrm{Ar}^{+}$ & $\mathrm{Ar}^{+}$ & $\mathrm{Ar}^{+}$ \\
$\Delta E, \mathrm{eV}$ & 5.2 & 4.4 & 4.6 & 4.6 & 4.0 & 4.5 \\
& 5.6 & 6.0 & 5.8 & 4.6 & 5.6 & 4.8 \\
$E_{m}, \mathrm{eV}$ & 3.4 & 4.0 & 4.0 & 3.6 & 3.2 & 3.4 \\
& 4.4 & 4.4 & 5.4 & 3.6 & 4.4 & 4.2 \\
\hline
\end{tabular}


protons. It was suggested that the formation as a result of the interaction of protons with the metal surface of unstable hydrogen-containing hydrides and hydroxides, characterized by ionic and ion-covalent types of bonds, can significantly increase the degree of atomic ionization by a mechanism similar to the mechanism of 'reaction emission'. The authors of Ref. [46] also note that an increase in the probability of ionization of sputtered particles upon transition from bombardment with argon or krypton to hydrogen may be attributed to additional ionization of the sputtered particles by secondary reflected protons.

Additional data on the mechanism of secondary ion emission during proton bombardment of a surface were obtained during study of the features of SIE for some alloys that possess different characteristics of phase equilibrium diagrams and binary compounds differing in the type of chemical bond.

\section{Secondary Ion Emission for Binary Alloys and Compounds}

A comparable investigation of the properties of SIE upon bombardment with proton and argon ions is carried out for $\mathrm{Cr}-\mathrm{V}$ (system with unlimited solubility of the components in the solid state) and $\mathrm{Fe}-\mathrm{V}$ (system with a presence of intermediate $\sigma$-phase) alloys [47].

The concentration dependences of SIE for $\mathrm{Cr}-\mathrm{V}$ alloys showed that the use of protons does not lead to a significant distortion of the linear dependence of the yield of ions on the concentration of components in the solid solution region. Thus, we can use the SIMS method and apply the proton bombardment for quantitative analysis of alloys with unlimited solubility of components. For the alloys of $\mathrm{Fe}-\mathrm{V}$ system, concentration dependences of the secondary ion yield of the components of alloys in the range of existence of $\sigma$-phase during sputtering of $\mathrm{H}^{+}$и $\mathrm{Ar}^{+}$are different. In case of using $\mathrm{Ar}^{+}$ions, a synchronous increase in the yield of ions of both components is observed, which is in a good agreement with earlier work [2-3], and when proton are bombarded, the dependences $Y_{i}^{+}(C)$ are more monotonic (see Fig. 5). In the latter case, the formation of $\sigma$-phase manifests itself in the change of the slope of $Y_{V}^{+}(C)$ dependence and practically does not reflect in the character of the $\mathrm{Fe}^{+}$ion emission. As it can be seen from this example, the effect of proton bombardment on the final yield of secondary ions may prove to be stronger than the effect of structural rearrangements in the alloy associated with the formation of the $\sigma$-phase. In some cases, for systems characterized by the formation of an intermediate $\sigma$ phase such as $\mathrm{Fe}-\mathrm{V}$, the use of protons may be more justified, since partial suppression of structural effects is observed in comparison with the primary argon ions and, therefore, a smaller error is introduced into the results of the quantitative analysis. 

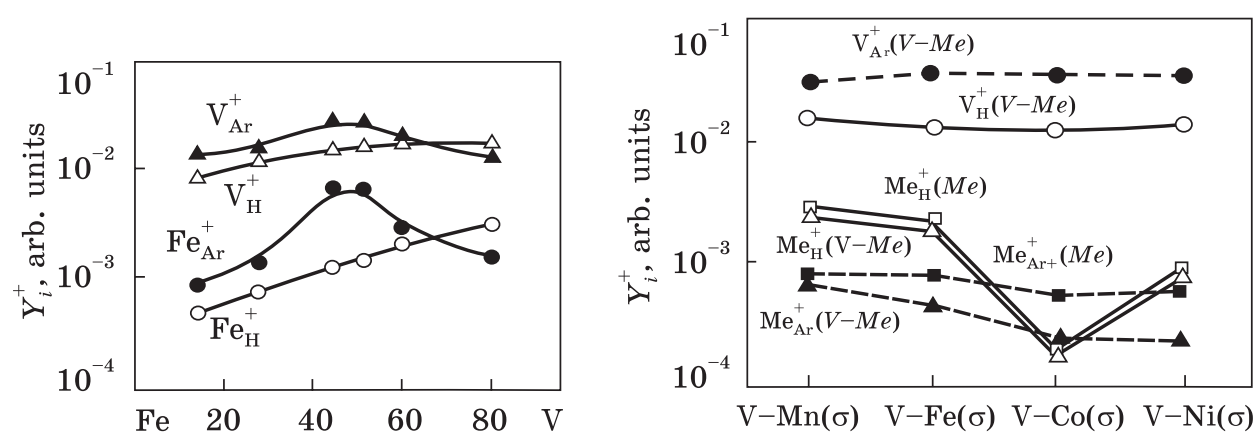

Fig. 5. Secondary ion yields of alloy components in the $\mathrm{Fe}-\mathrm{V}$ system bombarded with $\mathrm{H}^{+}$and $\mathrm{Ar}^{+}$

Fig. 6. Secondary ion yields of $\sigma$-phase components bombarded with $\mathrm{H}^{+}$and $\mathrm{Ar}^{+} v s$. component $B(\mathrm{Mn}, \mathrm{Fe}, \mathrm{Co}$, or $\mathrm{Ni})$

In order to study comprehensively an effect of $\sigma$-phase formation on the SIE, an additional investigation of SIE of $A_{n} B_{m}$-type $\sigma$-phases is carried out, where vanadium acts as an $A$ component, while $B$ component is addressed to another transition metal of the first period in the periodic table. The $\sigma$-phases are studied for the following compositions: $\mathrm{V}+80$ at. $\% \mathrm{Mn}, \mathrm{V}+\mathbf{5 5 . 5}$ at. $\% \mathrm{Fe}, \mathrm{V}+\mathbf{4 1 . 3}$ at. $\% \mathrm{Co}, \mathrm{V}+32$ at. $\% \mathrm{Ni}$.

Figure 6 shows yield of secondary ions of $\sigma$-phases versus the type (kind) of $B$ component. The elements are arranged in order of increasing their atomic numbers. For comparison, the values of the yield of secondary ions for pure $B$ components are also plotted. It can be seen that the $Y_{i}^{+}$dependences on the kind of $B$ element have general tendencies when the surface is sputtered with protons and argon ions. The yield of the secondary vanadium ions practically does not depend on the selection of $B$ component. The behaviour of the change of the yields of secondary ions of $B$ component from the $\sigma$-phases is similar to the change of corresponding values for pure metals. It should be noted that for the studied $\sigma$-phases, the yield of vanadium ions is always higher than the yield of secondary ions from pure vanadium, while the yield of ions of the second component is always lower than the corresponding characteristic

Table 2. Parameter $\boldsymbol{F}\left(Y_{i}^{+}\right)$for the $\sigma$-phase components sputtered by protons and argon ions

\begin{tabular}{|c|c|c|c|c|}
\hline$\sigma-$ phase & $F_{\mathrm{H}}\left(Y_{\mathrm{V}}^{+}\right)$ & $F_{\mathrm{Ar}}\left(Y_{\mathrm{V}}^{+}\right)$ & $F_{\mathrm{H}}\left(Y_{M e}^{+}\right)$ & $F_{\mathrm{Ar}}\left(Y_{M e}^{+}\right)$ \\
\hline $\mathrm{V}+80.0$ at. $\% \mathrm{Mn}$ & 2.9 & 4.4 & 0.99 & 0.98 \\
$\mathrm{~V}+55.5$ at. $\% \mathrm{Fe}$ & 2.5 & 5.6 & 0.91 & 0.48 \\
$\mathrm{~V}+41.3$ at.\% Co & 2.1 & 4.4 & 0.61 & 0.41 \\
$\mathrm{~V}+32.0$ at.\% Ni & 2.6 & 4.7 & 0.85 & 0.44 \\
\hline
\end{tabular}



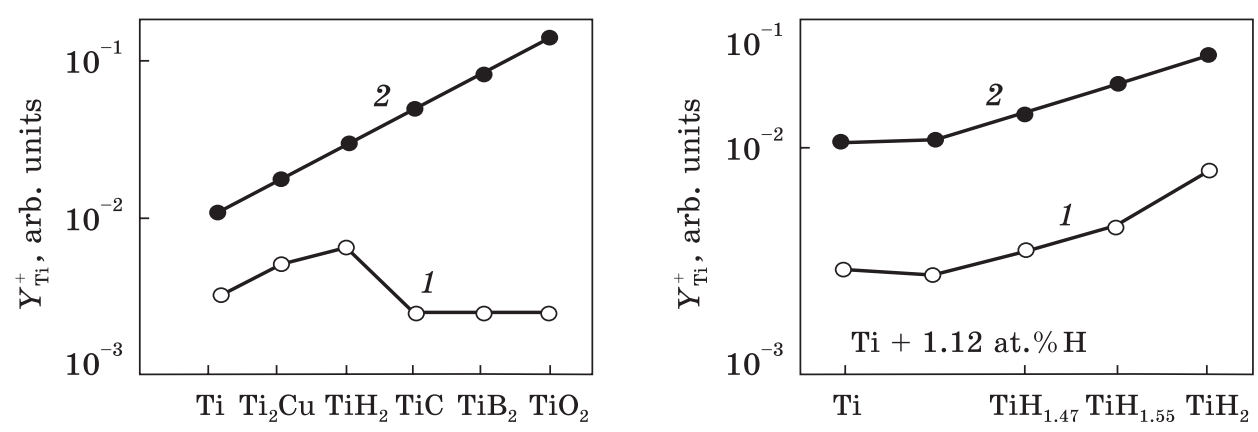

Fig. 7. Yield of secondary $\mathrm{Ti}^{+}$ions from binary titanium-based compounds bombarded with $\mathrm{H}^{+}(1)$ and $\mathrm{Ar}^{+}$(2) [48]

Fig. 8. Concentration curves for secondary $\mathrm{Ti}^{+}$ion yields in the $\mathrm{Ti}-\mathrm{H}$ system bombarded with $\mathrm{H}^{+}$(1) and $\mathrm{Ar}^{+}$(2) [48]

for the pure metal. Table 2 exhibits values of $F\left(Y_{i}^{+}\right)$parameter that represents a ration of the yield of secondary ions of the $\sigma$-phase components to the yield of ions of the corresponding pure metal. We can see that the effect of increasing the yield of secondary vanadium ions and decreasing the yield of secondary ions of the second component is less pronounced for proton bombardment. This result completely correlates with the results of analysis of $\mathrm{Fe}-\mathrm{V}$ alloys characterized by the formation of intermediate $\sigma$-phases.

Works [48, 49] deal with investigations of regularities of the SIE, where the subjects of the study were $\mathrm{Ti}_{2} \mathrm{Cu}$ intermetallide, titanium carbide, boride, and oxide, as well as model phases of stable compounds with a hydrogen as an origin component: $\alpha$-solid solution of hydrogen in titanium (1.12\% at. $\mathrm{H})$ and hydrides $\mathrm{TiH}_{1.47}, \mathrm{TiH}_{1.55}, \mathrm{TiH}_{2}$. Further, we will call the metal-metal compounds as metallic, and the metal with the metalloid as non-metallic compounds. For all considered binary titanium-based compounds subjected to Ar-ion bombardment, the yield of secondary $Y_{\mathrm{Ti}}^{+}$ions is higher than for pure titanium and increases according to the sequence $\mathrm{Ti} \rightarrow \mathrm{Ti}_{2} \mathrm{Cu} \rightarrow \mathrm{TiH}_{2} \rightarrow \mathrm{TiC} \rightarrow \mathrm{TiB}_{2} \rightarrow \mathrm{TiO}_{2}$ (see Fig. 7). The maximal yield of secondary $\mathrm{Ti}^{+}$ions occurs for titanium oxide, which well agrees with known works [2-4]. In case of the proton

Table 3. $\boldsymbol{F}\left(\boldsymbol{Y}_{M e}^{+}\right)$parameter for diborides and dioxides sputtered by protons and argon ions [48]

\begin{tabular}{|l|c|c||c|c|c|}
\hline Sample & $F_{\mathrm{H}}\left(Y_{M e}^{+}\right)$ & $F_{\mathrm{Ar}}\left(Y_{M e}^{+}\right)$ & Sample & $F_{\mathrm{H}}\left(Y_{M e}^{+}\right)$ & $F_{\mathrm{Ar}}\left(Y_{M e}^{+}\right)$ \\
\hline $\mathrm{CrB}_{2}$ & 0.92 & 29.0 & $\mathrm{SiO}_{2}$ & 0.80 & 42.0 \\
$\mathrm{VB}_{2}$ & 1.00 & 9.00 & $\mathrm{TiO}_{2}$ & 0.75 & 20.0 \\
$\mathrm{TiB}_{2}$ & 0.75 & 10.0 & & & \\
\hline
\end{tabular}


sputtering of the surface, the yield of $\mathrm{Ti}^{+}$ions emitted from $\mathrm{Ti}_{2} \mathrm{Cu}$, is also higher than yield of ions from pure titanium. Moreover, the effect of increase in emission is the same for primary argon ions and protons. However, maximal yield of ions is observed for titanium hydride. In this case, increase in emission for $\mathrm{TiH}_{2}$ during the proton bombardment, is commensurable with analogous effect observed during the sputtering of titanium hydride by Ar ions. When the surface of non-metallic compounds is bombarded with protons, there is an absolutely another regularity in comparison to the primary argon ions. The values of the yield of primary $\mathrm{Ti}^{+}$ions emitted from non-metallic compounds are commensurate with corresponding value for pure metal and slightly depend on the kinds of non-metallic component. Note that this anomaly is general for all studied non-metallic compounds of different (non)transition metals. As an example for some diborides and oxides, Table 3 contains values of $F\left(Y_{M e}^{+}\right)$parameter, which represents the ratio of the yield of the secondary metallic ions from non-metallic compounds to the yield of ions from corresponding metal during bombardment with protons and argon ions.

The anomalous behaviour of non-metallic compounds during bombardment by protons cannot be explained by the mechanism of differential surface sputtering, since in this case an analogous effect should be observed even more pronouncedly when the compounds are sputtered with argon ions. In our opinion, the observed anomaly can be explained from the positions of interaction of accelerated protons with the surface. Hydrogenation of the surface of non-metallic compounds leads to the formation of complex unstable carbohydrides, borohydrides and hydroxides, which, in turn, leads to a change in the character of the interatomic interaction of the atoms in the surface layer of the target.

The assumptions concerning the effect of surface hydrogenation on SIE have been carried out for model phases, where hydrogen is bound in stable compounds as an original component [48-49]. It was found that for each of bombarded gas, values for the yield of secondary $\mathrm{Ti}^{+}$ions from pure titanium, $\alpha$-solid solution, and hydrides are the values of the same order (Fig. 8). If primary argon and proton ions are used, a qualitatively analogous character of the concentration dependences of $\mathrm{Ti}^{+}$-ion yield is observed: within the $\alpha$-solid solution region, the concentration dependence of $Y_{\mathrm{Ti}}^{+}$is linear independent on concentration, while the $\mathrm{Ti}^{+}$ion yield from hydrides exceeds corresponding value for pure titanium and $\alpha$-solid solution. A further increase in the concentration of hydrogen leads to an increase in emission due to the formation of $\mathrm{Ti}-\mathrm{H}$ bonds: as the higher hydrogen content, as the stronger increase in emission. 


\section{Mechanisms of the Secondary Ion Emission Amplification under the Influence of Adsorption and Hydrogen Implantation}

The obtained experimental results indicate about prospects of using concepts of local surface bonds for describing emission from surfaces of transition metals during adsorption and simultaneous implantation of hydrogen from a bombarding beam. However, in all above-mentioned works, the mechanism of proton-stimulated emission is discussed mainly only qualitatively. The complexity of studies of the effect of hydrogen on SIE and the fundamental characteristics of the ion-bombarded surface, such as the work function of electrons, did not allow choosing an adequate model that could describe quantitatively the observed effects. To study the effect of hydrogen adsorption on the emission of secondary ions from a metal surface, a technique was developed for simultaneous measurements of SIE and the work function of electrons from a surface area directly exposed to ion bombardment, which was described earlier in Section. This technique was used to test the applicability of the tunnelling model [28] and the model of local bonds [31] to the case of amplification of SIE under the influence of adsorption and hydrogen implantation.

\section{Adsorption of Hydrogen}

Figure 9, $a$ presents dependence of the work function of electrons $\varphi$ on partial pressure of hydrogen $P_{\mathrm{H}}$ adsorbed onto Mo (111) surface during the sputtering with argon ions [35]. The work function decreases as the $P_{\mathrm{H}}$ increases. Note that in case of oxygen adsorption for analogous condition of Mo (111) sputtering by $\mathrm{Ar}^{+}$ions, the considerable changes of $\varphi$ were detected only for oxygen pressures exceeding $5 \cdot 10^{-4} \mathrm{~Pa}$, where dependence $\varphi\left(P_{\mathrm{H}}\right)$ actually reaches minimum. It is known that the concentration of adsorbate on the surface is determined by the ratio between the rate of adsorption of the injected gas and its sputtering rate by an ion beam. Therefore, significant changes in the work function of electrons in the pressure range up to $5 \cdot 10^{-4} \mathrm{~Pa}$ during the hydrogen adsorption and their absence in case of the oxygen adsorption mean that there is a certain mechanism that obstructs the hydrogen sputtering with an Ar-ion beam.

A theoretical justification for the possibility of hydrogen accumulation in the sputtered surface is reported in Ref. [50]. It is known that the sputtering of a surface atom is possible if the energy transferred to this atom during atomic collisions exceeds its binding energy with the surface [32]. This condition is not satisfied for light hydrogen atoms adsorbed into surfaces of heavy metals. Indeed, due to strong difference 
in masses of hydrogen and metal atoms $\left(M_{\mathrm{H}}=1\right.$ a.m.u. and $\left.M_{\mathrm{H}} \ll M_{M e}\right)$, the energy transfer coefficient expressed as

$$
\frac{4 M_{\mathrm{H}} M_{M e}}{\left(M_{\mathrm{H}}+M_{M e}\right)^{2}}
$$

will be small even for the central collision of particles. Therefore, the energy transferred to a hydrogen atom by a metal atom moving in a cascade of atomic collisions with an average energy $E_{\text {mean }}$ may also be less than the binding energy of a hydrogen atom to the surface of the metal $E_{\text {bond }}$, i.e.,

$$
\frac{4 M_{M e} E_{\text {mean }}}{\left(M_{M e}+1\right)^{2}}<E_{\text {bond }} .
$$

Solving Eq. (4) with respect to $E_{\text {mean }}$ one can say that $E_{\text {mean }}$ usually belongs to the range of $10-100 \mathrm{eV}$ depending on the target material and some other parameters of the bombarded beam. For instance, in case of a niobium, the cascade sputtering of hydrogen is a problematical, if $E_{\text {mean }}<92 \mathrm{eV}$. Thus, the cascade sputtering mechanism leads to a selective sputtering of the components: effective for matrix metal atoms and ineffective for impurity hydrogen atoms. In these conditions, hydrogen is sputtered mainly via direct knocking out of hydrogen atoms by bombarding ions. However, according to the literary data [51], the cross section of the direct knocking-out of recoil atoms is an order of magnitude smaller than the cross section for cascade sputtering. Therefore, the impurity hydrogen atoms tend to accumulation in the sputtered metal surface up to equilibrium concentrations determined by the ratio between the cross sections of all possible mechanisms of sputtering for metals and impurities. Hydrogen enrichment of the surface was also observed in Ref. [52] when niobium hydrides with different hydrogen concentrations were sputtered with $\mathrm{Ar}^{+}$ions.

Figure 9, $b$ illustrates how yield of the secondary molybdenum ions $K_{\mathrm{Mo}}^{+}$increases during hydrogen adsorption [35]. Like the work function of the electrons, the yield of secondary molybdenum ions also proved to be insensitive to the adsorption of oxygen up to the oxygen pressure of $5 \cdot 10^{-4} \mathrm{~Pa}$, thereby characterizing the differences in the mechanisms of
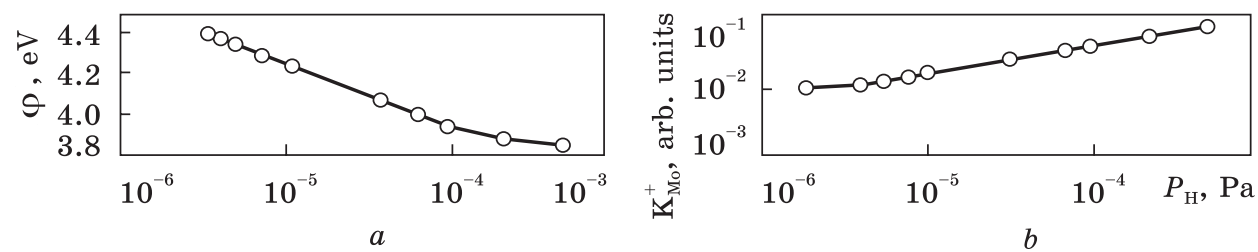

Fig. 9. Electron work function $(a)$ and yield of secondary molybdenum ions $(b) v s$. hydrogen pressure adsorbed on the Mo(111) surface during sputtering of $\mathrm{Ar}^{+}$ions [35] 
hydrogen and oxygen sputtering. Thus, these results are direct experimental confirmation of the accumulation of hydrogen in the sputtered surface.

The opposite tendencies in the variations of the $\varphi\left(P_{\mathrm{H}}\right)$ and $K_{\mathrm{Mo}}^{+}\left(P_{\mathrm{H}}\right)$ dependences indicate the inapplicability of the tunnelling model [28] to the case of hydrogen adsorption, since, according to this model, the decrease of $\varphi$ should result to the decreasing the probability of positively charged secondary ions' formation.

Among the models explaining the enhancement of SIE due to formation of local chemical bonds of metal atoms and adsorbate [29-31], the most developed in terms of quantitative description of the observed effects is the model reported in work [31]. According to this model, in case of a small coverage of the surface, the ionization probability of the sputtered metal atoms $R_{M e}^{+}$exponentially depends on the concentration of adsorbed gas $C_{\mathrm{H}}$ :

$$
R_{M e}^{+}=R_{0} \exp \left\{N C_{\mathrm{H}}\left[\left(1 / a_{0}\right)^{d}-1\right]\right\},
$$

where $\alpha_{0}, N$, and $d$ are model parameters.

Findings in the work [35] (see also Fig. 9, a) show that, similarly to Eq. (5), the dependence of yield of secondary molybdenum ions on the work function of electrons within the range of $\varphi \in[4.4,3.9] \mathrm{eV}$ (i.e., in the range of small coverage of the metallic surface by the hydrogen) is exponential indeed and reads as

$$
K_{\mathrm{Mo}}^{+}=\kappa \exp (-2.8 \varphi) .
$$

Consequently, these results support the conclusion that the enhancement of secondary metal ions emission under the influence of hydrogen adsorption is caused by the formation of $M e-\mathrm{H}$ surface bonds and this effect can be quantitatively interpreted within the framework of the local bond breakage model [31].

\section{Implantation of Hydrogen}

The important role of surface hydrogen-containing bonds in the mechanism of the enhancement of SIE, caused by the substitution of bombarding argon ions by a proton beam, was noted earlier in the discussion of SIE of transition metals, binary metal alloys and compounds. Figure 10, $a$ illustrates a correspondence between the measured values of $R_{i}^{+}$for the first large period of the periodic table (Fig. 2,c) and published [51] values of the binding energy of hydrogen in the surfaces of these metals $E_{\mathrm{H}}$. One can see that the ionization probability correlates with a bond strength $M e-\mathrm{H}$.

A more complete correlation can be obtained if we calculate the probability of ionization of sputtered metal atoms for breaking $M e-\mathrm{H}$ 

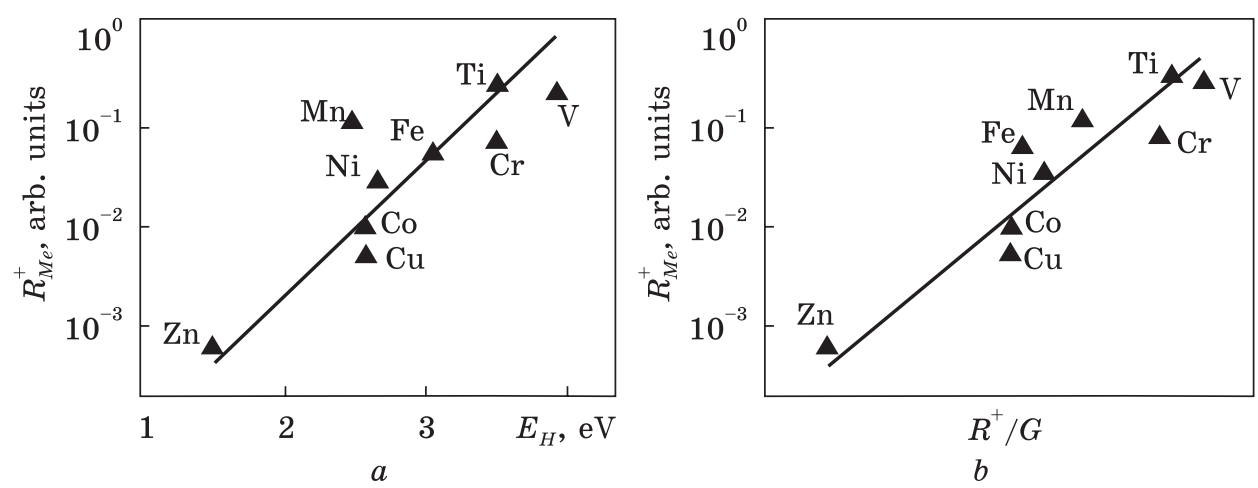

Fig. 10. Ionization probability of sputtered atoms emitted from the respective pure metals under $\mathrm{H}^{+}$-bombardment $v s$. the binding energy of hydrogen in the metal surfaces $(a)$ and parameter $R^{+} / G(b)$ [35]

surface bonds in the framework of models of discontinuity of local bonds $[29,30]$. In accordance with Ref. [30], ionization probability can be determined (with accuracy to unknown model parameter $G$ ) from as follows:

$$
\frac{R^{+}}{G}=\exp \left(\frac{-2 \pi H^{2}}{v(I-A)^{2}}\right),
$$

where $H$ is a matrix transition element, $v$ and $I$ are the ionization rate and potential, and $A$ is an electron affinity of the vacancy formed in the surface on the site of the sputtered atom. The values of $R^{+} / G$ calculated via Eq. (7) are compared in Fig. 10, $b$ with those measured experimentally. We can see that expression (7) gives satisfactory quantitative description of the hydrogen-stimulated emission of the secondary ions from the metal surfaces.

However, the uncertainty in calculation of the model parameter $G$ did not allow achieving good quantitative interpretation of the effect of the secondary ion emission amplification for the metals of different periods of the periodic table. While the use of the values of $E_{\mathrm{H}}$ gives a possibility for adequate prediction of the tendency of $K_{i}^{+}$change depending on the atomic number in the metal series: from titanium to aurum.

\section{Conclusions}

The review presents the results of a comparative systematic study of the regularities of SIE for various metals, alloys and isolated compounds with different electronic structure, phase and stoichiometric composition, when they are bombarded with protons and argon ions under identical conditions. It is shown that the bombardment of metal targets by protons leads to an anomalously high ionization probability of sputtered particles, a decrease in the average energy of secondary ions, and a par- 
tial suppression of structural, concentration, and phase effects. It has been established that the emission processes during the proton bombardment obey the basic laws revealed for bombardment with inert gas ions regarding the secondary ion yield dependencies on the atomic number of metals and concentration ratios in alloys, intermetallic compounds and hydrides. At the same time, in case of non-metallic compounds bombarded with protons, a regularity, inverse to that observed for inert gases, is revealed. The values for the secondary metal ions' yields from these compounds are commensurable with the corresponding value for pure metal and depend weakly on the type of the non-metal. A technique for simultaneous studies of secondary ion emission and the work function of the bombarded surface is proposed. The anomalously high probability of ionization of atoms sputtered from metals by accelerated protons is explained by the formation of $M e-\mathrm{H}$ surface bonds. The effects of the SIE amplification under the influence of adsorption, as well as under the influence of hydrogen implantation from a bombarding beam, are explained quantitatively within the framework of the known models of the secondary ion emission mechanism. These models take into account the breakage of chemical bonds between metal atoms and adsorbate during the sputtering and subsequent ionization of sputtered metal atoms.

\section{REFERENCES}

1. V.I. Veksler, Vtorichnaya Ionnaya Ehmissiya Metallov [Secondary Ion Emission of Metals] (Moscow: Nauka: 1978) (in Russian).

2. V.T. Cherepin and M.A. Ivanov, Vtorichnaya Ionno-Ionnaya Ehmissiya Metallov i Splavaov [Secondary Ion-Ion Emission of Metals and Alloys] (Moscow: Nauka: 1975) (in Russian).

3. V.T. Cherepin, Ionnyy Zond [Ion Probe] (Kiev: Naukova Dumka: 1981) (in Russian).

4. V.T. Cherepin, Ionnyy Mikrozondovyy Analiz [Ion Microprobe Analysis] (Kiev: Naukova Dumka: 1981) (in Russian).

5. V.T. Cherepin and M.A. Vasiliev, Metody i Pribory dlya Analiza Poverkhnosti Materialov [Methods and Devices for Analysis of the Material Surfaces] (Kiev: Naukova Dumka: 1982) (in Russian).

6. V.T. Cherepin, Secondary Ion Mass Spectroscopy of Solid Surfaces (Oxford: Alden Press: 1987).

7. V.E. Yurasova, Vzaimodeistvie Ionov s Poverkhnostyu [Interaction of Ions with Surface] (Moscow: Prima B: 1999) (in Russian).

8. R.J.-B. Castaing and G. Slodzian, C.R. Acad. Sci. B, 251: 1010 (1960).

9. Ya.M. Fogel, Sov. Phys. Usp., 10: 17 (1967).

10. G. Slodzian and J.-F. Hennequin, C.R. Acad. Sci., B, 263, No. 22: 1246 (1966).

11. A. Benninghoven, Surf. Sci., 53, No. 3: 596 (1975).

12. A. Benninghoven, F.G. Rudenauer, and H.W. Werner, Secondary Ion Mass Spectrometry: Basic Concepts, Instrumental Aspects, Applications, and Trends (New York: Wiley: 1987). 
13. L. A. Giannuzzi, B. I. Prenitzer, and B. W. Kempshall, Ion-Solid Interaction, (Berlin: Springer: 2005).

14. J.C. Lee, H.J. Kang, K.J. Kim, Y.S. Kim, and D.W. Moon, Surf. Sci., 324: 338 (1995).

15. V.P. Ivanov and S. N. Trukhan, J. Struct. Chem., 55, No. 5: 995 (2014).

16. S. Fajardoa, D.M. Bastidasa, M.P. Ryanb, M. Criadoc, D.S. McPhailb, and R.J. H. Morrisd, Appl. Surf. Sci., 288: 423 (2014).

17. V.V. Khvostov, I.K. Khrustachev, K.F. Minnebaev, E.Yu. Zykova, and V.E. Yurasova, Vacuum, 100: 84 (2014).

18. K.F. Minnebaev, A.A. Khaidarov, and V.E. Yurasova, Surface Investigation X-Ray, Synchrotron and Neutron Techniques, 9: No. 5: 1107 (2015).

19. S.A. Firstov, N.A. Krapivka, M.A. Vasiliev, S.I. Sidorenko, and S.M. Voloshko, Powder Metallurgy, No. 07/08: 98 (2016) (in Russian).

20. M.A. Vasiliev, A.A. Kosyachkov, I.N. Makeeva, and V.T. Cherepin, Poverkhnost', No. 1: 103 (1982) (in Russian).

21. N.Kh. Dzhemelev and R.T. Kurbanov, Poverkhnost', No. 1: 56 (1984).

22. M.A. Vasiliev and I.N. Makeeva, Zavodskaya Laboratoriya. Diagnostika Materialov, 64, No. 9: 26 (1997).

23. M.A. Vasiliev, I.N. Dubinskiy, A.A. Kosyachkov, I.N. Makeeva, S.P. Chenakin, V.T. Cherepin, and V.G. Kostyuchenko, Sposob Mass-Spektroskopicheskogo Posloinogo Analiza Tverdykh Tel, A. s. No. 1138855 (Published 07.02.1985. Bulletin No. 5).

24. M. Junack, A. Eicke, W. Sichtermann, A. Benninghoven, Ion Formation from Organic Solids (Springer Series in Chemical Physics, 25) (Berlin-Heidelberg: Springer: 1983), p. 177.

25. N.J. Popczun, L. Breuer, A. Wucher, and N. Winograd, J. Am. Soc. Mass. Spectrom., 28: 1182 (2017).

26. J. Brison, S. Muramoto, and D. G. Castner, J. Phys. Chem. C, 114, No. 12: 5565 (2010).

27. J. Matsuo, S. Ninomiya, H. Yamada, K. Ichiki, Y. Wakamatsu, M. Hada, T. Seki, and T. Aoki, Surf. Interface Anal., 42, Nos. 10-11: 1612 (2010).

28. M.L. Yu and N.D. Lang, Nucl. Instr. Meth. Phys. Res. B, 14: 403 (1986).

29. G. Slodzian, Surf. Sci., 48: 161 (1975).

30. M.L. Yu, Nucl. Instr. Meth. Phys. Res. B, 18: 542 (1986).

31. H. Oechsner, Z. Sroubek, Surf. Sci.,127: 10 (1983).

32. P. Sigmund, Phys. Rev., 184, No. 2: 416 (1969).

33. M.I. Guseva and Yu.V. Martynenko, J. Nucl. Mater., 63, No. 1: 241 (1976).

34. N.V. Plishivtsev, Fizicheskie Problemy Katodnogo Rasspyleniya [Physical Problems of Cathode Sputtering] (Moscow: Izdatelstvo IAEh AN SSSR: 1979).

35. A.A. Kosyachkov, Poverkhnost', No. 4: 25 (1994).

36. V.T. Cherepin, A.A. Kosyachkov, I.N. Dubinskiy, and V.Eh. Is'yanov, Pribory $i$ Tekhnika Ehksperimenta, No. 1: 152 (1986) (in Russian).

37. V.V. Nemoshkalenko, Ehlektronnaya Spektroskopiya Kristallov [Electron Spectroskopy of Crystals] (Kiev: Naukova Dumka: 1976) (in Russian).

38. A.A. Kosyachkov, Poverkhnost', No. 9: 128 (1989) (in Russian).

39. K. Wittmaack, Phys. Scr., 6: 71 (1983).

40. M.A. Vasiliev, A.A. Ksyachkov, I.N. Makeeva, and V.T. Cherepin, Metallofizika, 4, No. 3: 69 (1982) (in Russian).

41. V.T. Cherepin, A.A. Kosyachkov, and I.N. Makeeva, Secondary Ion Mass Spectrometry-SIMS IV (Eds. A. Benninghoven, J. Okano, R. Shimizu, and H.W. Werner) (Berlin-Heidelberg: Springer-Verlag: 1984), p. 57. 
42. W. Gerhard, Z. Phys. B, 22: 31 (1975).

43. K .Wittmaack, Phys. Lett. A, 69: 322 (1979).

44. I.S. Bitenskiy and Eh.S. Paralis, Zhurnal Tekhnicheskoy Fiziki, 48: 1941 (1978) (in Russian).

45. J.M. Schroeer, T.N. Rhodin, and R.C. Bradley, Surf. Sci., 34, No. 3: 571 (1973).

46. K.F. Minnebaev, A.E. Saburov, and V.S. Chernysh, Poverkhnost', No. 11: 150 (1987) (in Russian).

47. O.A. Bannykh, P.B. Budberg, and S.P. Alsova, Diagrammy Sostoyaniya Dvoinykh i Mnogokomponenthykh Sistem na osnove Zheleza [State Diagrams of Binary and Multicomponent Iron-Based Systems] (Mosow: Metallurgiya: 1986) (in Russian).

48. M.A. Vasil'ev, A.A. Kosyachkov, I.N. Makeeva, and V.T. Cherepin, Metallofizika, 9, No. 1: 43 (1987) (in Russian).

49. M.A. Vasil'ev, A.A. Kosyachkov, I.N. Makeeva, and V.T. Cherepin, Poverkhnost', No. 8: 39 (1987) (in Russian).

50. A.A. Kosyachkov, V.T. Cherepin, and S.M. Chichkan', Pis'ma v Zhurnal Tekhnicheskoj Fiziki, 17, No. 5: 61 (1991).

51. K.W. Frese, Surf. Sci., 182: 85 (1987).

52. H. Zuchner and T. Bruning, J. Alloys and Compounds, 231: 347 (1995).

Received November 28, 2017;

in final version, January 22, 2018

В.Т. Черепін, М.О. Васильєв, І.М. Макеєва, В.М. Колесник Інститут металофізики ім. Г.В. Курдюмова НАН України, бульв. Академіка Вернадського, 36, 03142 Київ, Україна

C.M. Волошко

Національний технічний університет України «Київський політехнічний інститут імені Ігоря Сікорського», просп. Перемоги, 37, 03056 Київ, Україна

\section{ВТОРИННА ЙОННА ЕМІСІЯ ПРИ БОМБУВАННІ МЕТАЛЕВИХ ПОВЕРХОНЬ ПРОТОНАМИ}

В оглядовій статті аналізуються результати досліджень закономірностей і особливостей вторинної йонної емісії при бомбардуванні металевих поверхонь найлегшими йонами - протонами, що мають найнижчі коефіцієнти розпорошення i, отже, спричинюють мінімальну ерозію досліджуваної поверхні. Інтерес до вивчення закономірностей та особливостей протонної мас-спектрометрії зумовлено пошуком нових фізичних можливостей підвищення виходу вторинних йонів 3 метою поліпшення аналітичних характеристик методи мас-спектрометрії вторинних йонів. У роботі наведено результати порівняльного систематичного дослідження процесів емісії вторинних йонів перехідних металів, бінарних стопів і сполук, що відрізняються електронною структурою, фазовим і стехіометричним складами, при бомбардуванні протонами та йонами Аргону. Достовірно встановлено, що процеси вторинної йонної емісії при бомбардуванні протонами мають основні закономірності, виявлені при бомбардуванні йонами інертних газів, у частині залежности від атомового номеру металів і концентраційних співвідношень у бінарних стопах і сполуках, але принципово відрізняються аномально високою ймовірністю йонізації частинок, розпорошених з металевих мішеней. Показано, що в разі бомбардування протонами багатокомпонентних мішеней спостерігається 
зменшення структурних, фазових та інших матричних ефектів, істотних при бомбардуванні йонами інертних газів. Ефекти посилення вторинної йонної емісії під впливом адсорбції та імплантації Гідрогену з бомбардувального пучка протонів пов'язано з утворенням поверхневих зв'язків $M e-\mathrm{H}$ і кількісно пояснено в рамках моделів, що враховують розрив хемічних зв'язків атомів металу й адсорбату в процесі розпорошення та подальшої йонізації розпорошуваних атомів металу.

Ключові слова: вторинна йонна емісія, мас-спектрометрія вторинних йонів, протони, йони Аргону, металева поверхня, робота виходу електронів.

В.Т. Черепин, М.А. Васильєв, И.М. Макеєва, В.М. Колесник

Институт металлофизики им. Г.В. Курдюмова НАН Украины, бульв. Академика Вернадского, 36, 03142 Киев, Украина

С.М. Волошко

Национальный технический университет Украины «Киевский политехнический институт имени Игоря Сикорского», просп. Победы, 37, 03056 Киев, Украина

\section{ВТОРИЧНАЯ ИОННАЯ ЭМИССИЯ ПРИ БОМБАРДИРОВКЕ МЕТАЛЛИЧЕСКИХ ПОВЕРХНОСТЕЙ ПРОТОНАМИ}

В обзорной статье содержатся результаты исследований закономерностей и особенностей вторичной ионной эмиссии при бомбардировке металлических поверхностей самыми лёгкими ионами - протонами, которые обладают наиболее низкими коэффициентами распыления и, следовательно, вызывают минимальную эрозию исследуемой поверхности. Интерес к изучению закономерностей и особенностей протонной масс-спектрометрии вызван поиском новых физических возможностей повышения выхода вторичных ионов с целью улучшения аналитических характеристик метода масс-спектрометрии вторичных ионов. В работе приведены результаты сравнительного систематического исследования процессов эмиссии вторичных ионов переходных металлов, бинарных сплавов и соединений, отличающихся электронной структурой, фазовым и стехиометрическим составами, при бомбардировке протонами и ионами аргона. Достоверно установлено, что процессы вторичной ионной эмиссии при бомбардировке протонами подчиняются основным закономерностям, выявленным при бомбардировке ионами инертных газов, в части зависимостей от атомного номера металлов и концентрационных соотношений в бинарных сплавах и соединениях, но принципиально отличаются аномально высокой вероятностью ионизации частиц, распылённых из металлических мишеней. Показано, что в случае бомбардировки протонами многокомпонентных мишеней, наблюдается частичное подавление структурных, фазовых и других матричных эффектов, существенных при бомбардировке ионами инертных газов. Эффекты усиления вторичной ионной эмиссии под влиянием адсорбции и имплантации водорода из бомбардирующего пучка протонов связаны с образованием поверхностных связей $M e-\mathrm{H}$ и количественно объяснены в рамках моделей, учитывающих разрыв химических связей атомов металла и адсорбата в процессе распыления и последующей ионизации распыляющихся атомов металла.

Ключевые слова: вторичная ионная эмиссия, масс-спектрометрия вторичных ионов, протоны, ионы аргона, металлическая поверхность, работа выхода электронов. 